\title{
Comparison of Print Modules and E-Modules to the Tolerance Character of Students
}

\section{Syahrial $^{1 *}$, Asrial $^{2}$, Dwi Agus Kurniawan ${ }^{3}$, Latipia Damayanti ${ }^{4}$}

1, 2, 3, 4 Faculty of Teacher Training and Education, Jambi University, Indonesia

\section{ART ICLE INFO}

\section{Article history:}

Received March 07, 2021

Revised March 10, 2021

Accepted May 11, 2021

Available online May 25, 2021

Kata Kunci:

Karakter Toleransi, Modul

Keraifan Lokal

Keywords:

Tolerance Character, Module, Local Wisdom

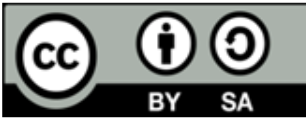

This is an open access article under the CC BY-SA license.

Copyright (C) 2021 by Author. Published by Universitas Pendidikan Ganesha.

\begin{abstract}
A B S T R A K
Dewasa ini, karakter toleransi pada siswa sekolah dasar mengalami degradasi. Padahal karakter toleransi merupakan salah satu karakter yang penting dimiliki siswa dalam kehidupan sosialnya. Penelitian ini bertujuan untuk menganalisis perbandingan respon dan karakter tolerasi siswa yang belajar menggunakan dua modul pembelajaran yang berbeda, yaitu modul elektronik dan modul cetak. Penelitian ini merupakan penelitian deskriptif kuantitatif. Populasi dalam penelitian ini berjumlah 243 siswa. Penentuan sampel dilakukan dengan menggunakan teknik purposive sampling, sehingga diperoleh sampel sebanyak 32 siswa. Pengumpulan data dalam penelitian ini menggunakan instrumen berupa kuesioner respon siswa dan kuesioner karakter toleransi. Instrumen yang digunakan tersebut telah diuji validitas dan reliabilitasnya. Data yang telah dikumpulkan kemudian dianalisis dengan menggunakan statistik deskriptif dan inferensial, uji asumsi (normalitas dan homogenitas) dan uji hipotesis (Uji-t). Hasil penelitian menunjukkan bahwa respon siswa lebih dominan saat menggunakan modul elektronik berbasis kearifan lokal daripada modul cetak. Karakter toleransi yang muncul juga lebih terlihat saat menggunakan modul elektronik berbasis kearifan lokal ngubat padi daripada modul cetak. Berdasarkan temuan tersebut, disimpulkan bahwa respon siswa saat menggunakan modul elektronik lebih baik daripada menggunakan modul cetak. Karakter toleransi siswa juga dapat dilihat pada penerapan modul elektronik dan modul cetak. Sehingga disarankan agar modul elektronik berbasis kearifan lokal digunakan sebagai bahan ajar tambahan dalam pembelajaran di sekolah dasar.
\end{abstract}

\begin{abstract}
A B S T R A C T
Nowadays, the character of tolerance in elementary school students is experiencing degradation. Whereas the character of tolerance is one of the important characters possessed by students in their social life. This study aims to analyze the comparison of responses and tolerance characteristics of students who learn to use two different learning modules, namely the electronic module and the printed module. This research is quantitative descriptive. The population in this study amounted to 243 students. Determination of the sample is done by using the purposive sampling technique, to obtain a sample of 32 students. Data collection in this study used instruments in the form of student response questionnaires and tolerance character questionnaires. The instrument used has been tested for validity and reliability. The collected data were then analyzed using descriptive and inferential statistics, assumption tests (normality and homogeneity), and hypothesis testing (t-test). The results showed that students' responses were more dominant when using the electronic module based on local wisdom than the printed module. The tolerance character that appears is also more visible when using an electronic module based on the local wisdom instead of a printed module. Based on these findings, it was concluded that students' responses when using the electronic module were better than using the print module. Students' tolerance character can also be seen in the application of electronic modules and print modules. So it is recommended that the electronic module based on local wisdom be used as additional teaching materials in learning in elementary schools.
\end{abstract}

\section{INTRODUCTION}

Education is a learning process that aims to change a person to have new knowledge, new skills and perform well. Education is a place for knowledge, self-development, and success and can increase achievement in literacy (Diputra, 2016; Proity, 2015). Education is a process of improving the quality of life and learning and instilling the skills learned by students (Kurniawan et al., 2020; Rachmawati et al., 2014). A good education can be seen that there are positive changes in students. It depends on how the teacher to make it happen. Understanding the impact of technology and finding the best way to integrate technology into the classroom is very important (Kwon, 2017). One way to improve education is to improve the quality of learning, namely by updating, approaching or improving according to the student's personality (Kurniawan et al., 2020). The role of education is basically an indicator of the glory of a nation 
(Al Aslamiyah et al., 2019). Therefore, a teacher should be more creative and innovative in designing meaningful learning for students. Because in this era of globalization all information becomes easy to access, including ways to make learning more interesting. Information technology is a technology that combines computers with high-speed communication lines that carry data, voice and video (Inah, 2013). A student takes education to get the best education in school. The best education is a right for all human beings without any limitations and differences (Rachmawati et al., 2014). This is no stranger to Indonesian educators, because the progress of a country depends on how it is educated. As technology develops, Indonesia also feels this progress. Human life is strongly influenced by the development of science and technology (Budiman, 2017). The development of science supports the creation of new technologies that mark the progress of the times (Lestari \& Parmiti, 2020).

Information technology can be simply viewed as the science needed to manage information so that it can be easily searched or recovered (Husaini, 2017). ICT has a continuous process, ICT is developing very quickly (Ritzhaupt et al., 2013). Technology can be used by teachers to help find information in the form of teaching materials. Textbooks are all types of textbooks that are used to assist teachers in teaching and learning activities in the classroom. The material in question can be in the form of written material or unwritten material. The lack of material forces teachers to retreat to their own resources and design their own materials. Teaching materials arranged in textbooks can be in the form of textbooks, modules, handouts, student worksheets or can also be packaged in electronic form by utilizing digital technology (Kusmana et al., 2020). Modules are written textbooks. Modules are usually used as additional teaching materials. Learning modules are needed as learning resources for students so that they can understand the learning material more easily. This helps teachers in delivering learning materials (Mustadi et al., 2019). However, with the development of ICT, the module has now turned into an e-module or known as an electronic module. Technological developments also affect the development of teaching materials among lecturers and students, one of which is the electronic module (Darmayasa et al., 2018; Kurniawati, 2020). Because of various considerations if you have to use a print module. When viewed from its use, printed books are quite expensive, cannot display videos, moving images, animations and audio (Anandari et al., 2019).

Therefore, teachers must be able to operate computers in order to make more practical teaching materials, in the form of electronic modules. One way to make it easier for educators to deliver learning materials is to use learning modules (Bupu et al., 2018; Purwanto et al., 2020). Modules can provide opportunities for students to explore and construct their own knowledge in accordance with the situation and conditions of the students' social environment (Bupu et al., 2018). One of the advantages of the electronic module is that it is equipped with complete facilities with topic discussions but the language used is easier for students to understand (Purwanto et al., 2020). The electronic module used must be designed by the teacher very attractively, such as including some pictures and videos in the module so that students do not feel bored in the learning process and learning objectives can be achieved easily (Asrial et al., 2020). The learning module was developed with a flipbook maker application to be able to display images and videos, animation and reconstruction of local wisdom processes that can make students more interested (Suryani et al., 2019). This is done so that learning in the classroom is carried out well and is more interesting. The concepts received from the module are expected to be applied by students in the surrounding environment. Because elementary school students have the characteristics of learning with real things. Students no longer need to imagine abstract material, because the electronic module will make the material more concrete (Dewi \& Susilowati, 2017). So, a teacher must be able to guide learning well. Therefore, the experience of a teacher strongly supports the creation of more innovative learning, because the teacher's task is to create fun learning so that student learning outcomes are satisfactory. One of the most important tasks of teachers related to teaching materials is to present experiences that will enable students to gain educational attainment related to subjects for academic purposes and to adopt students' moral attitudes (Saglam, 2011). A teacher must be broad-minded and have character to be able to provide meaningful learning for students. Because teachers who have quality will give birth to quality successors as well. Teaching materials delivered by a teacher should be able to instill character education in students through culture and local wisdom that exists around students (Nurkhalisa \& Ummayah, 2015).

Local wisdom is the ability to adapt, regulate, and cultivate the influence of nature as well as other world cultures which is the driving force behind the transformation and creation of Indonesia's extraordinary cultural diversity. Local wisdom has several functions, among others; educational and scientific functions (Ismail et al., 2019). Local wisdom is the cultural values contained in an area that must be preserved because it contains values that can shape the character of students. Teachers can develop materials based on local wisdom with various activities that are expected to develop students' characters such as the character of cooperation, tolerance, and caring attitude (Rachmadyanti, 2017). In improving 
good character education in accordance with the ideals of the Indonesian nation, teachers as the spearhead of education must be good at managing learning (Manurung et al., 2018). Teachers with good personalities can provide understanding and increase the character of education in schools (Lukman et al., 2021). In line with that, local wisdom that exists in Indonesian society plays a role in building the character of a nation, such as mutual cooperation, religion, tolerance, and so on (Subali et al., 2015). Character does not form by itself, it must be instilled and shaped so that it can become a dignified nation to modernize the character of students through education (Kim, K. et al., 2018; Sanjaya et al., 2021). Character education here is education with the process of getting children to practice the good qualities that are in themselves so that the process can become a habit in children (Hanani, 2016). In the concept of character education which pays great attention to stimulation for children to learn a lot and develop their potential and interests which will provide strong experiences and memories (Dewia \& Alam, 2020). In this case the character to be improved is the character of tolerance. The character of tolerance serves to grow the competence of students' local wisdom (Supriyanto \& Wahyudi, 2017). Tolerance is harmony in difference (Sahal et al., 2018). In that view, the purpose of tolerance is expressed, namely to build peace in social life despite differences, thus it can be concluded that tolerance is an important factor in life. Because without tolenation there will be a lot of problems caused by the many differences. Intolerance is used to describe situations of violence, discrimination, violation of personal abilities, imbalance, the desire to unite (Chistolini, 2017; Nagovitsyn et al., 2018).

With this character problem, here the researcher tries to introduce electronic module teaching materials based on local wisdom of ngubat padi which is rich in character values that exist in the community. The local wisdom of ngubat padi is one of the local wisdoms in Tebo district that needs to be preserved so that the character of the child that is expected to remain in him. Character education is needed in basic education, especially for the character of tolerance. In this study, the expected result is that with the application of electronic modules based on local wisdom in learning, students become characters with character. Especially have a high sense of tolerance. The importance of measuring the character of tolerance and student responses when learning using electronic modules is to create a new learning atmosphere so that students do not get bored in learning activities and are expected to form student characters for the future, namely the character of tolerance. Electronic modules also help teachers to make students more active and independent so that teaching materials in the form of electronic modules can be used (Herawati \& Muhtadi, 2018). In addition, the use of electronic modules is very effective in improving student learning outcomes (Prasetiyowati, 2015). Therefore, the researchers tried to apply an electronic module based on local wisdom of rice cultivation which is rich in character values, especially the character of tolerance. This study aims to find out how the fifth grade students of SDN 45/1 Sridadi responded when using the print module; how did the fifth grade students of SDN 45/1 Sridadi respond when using the electronic module; how is the tolerance character of fifth graders at SDN 45/1 Sridadi when using the print module; and how is the tolerance character of class V students at SDN 45/1 Sridadi when using electronic modules.

\section{METHOD}

This research was conducted in class $\mathrm{V}$, theme 8 , sub-theme 1 learning 3 . In the field, learning using electronic modules based on local wisdom of ngubat padi has not been found. Therefore, the researcher offers a solution by introducing an electronic module based on local wisdom of ngubat padi for additional teaching materials as a learning companion in class $\mathrm{V}$, theme 8 , sub-theme 1 , learning 3 , to see a comparison of responses and tolerance characters that appear during learning. This research is a type of quantitative research with a comparative study that compares two or more variables. Comparative design is a study that compares the variables used (Abdurokhim, 2016; Bahiu et al., 2015; Kaunang, 2013). The variables analyzed are based on two things, the independent variable and the dependent variable. This study uses two independent variables, namely the print module and the electronic module. The dependent variable is the character of students' tolerance and response when using teaching materials. The population used in this study were all students of SDN 45/I Sridadi. While the samples used in this study were all students of class V SDN 45/I Sridadi, totaling 32 students.

The sampling technique is a sampling technique that will be used to determine the sample used in a study (Sugiyono, 2018). In this study, the sampling technique used is the nonprobability group, namely purposive sampling which has an understanding of the sampling technique with certain considerations. This sampling technique was chosen because in this study there are certain criteria to be studied, where all students of SDN 45/I Sridadi are 243 students and the criteria taken in this study are fifth grade students at the school. In determining the sample, a sampling technique is used, namely purposive sampling whose sample determination technique is carried out with certain considerations (Sugiyono, 
2018). Where the criteria applied by the researcher is the consideration of the state of the school and the students, the schools studied by the researchers still use a lot of non-electronic-based teaching materials but students still lack tolerance character, therefore researchers are interested in conducting research by implementing electronic modules to see a relationship with the character of tolerance. So it is imperative that choosing how to obtain data and from whom the data will be obtained is carried out with good judgment, especially because no amount of analysis can replace data that is collected incorrectly (Etikan et al., 2015).

The study was conducted using quantitative data obtained through the provision of questionnaires and surveys. Survey research is based on deductive logic, which starts by using a basic theory and ends with analysis of measurement data (Maksum, 2012). The questionnaire used is a student response questionnaire when implementing teaching materials in the form of modules. Table 1 shows a grid of student responses to the print module and the electronic module.

Table 1. Student Response Questionnaire Grid

\begin{tabular}{cccc}
\hline No & Assessment Aspect & Statement & Number of Items \\
\hline 1 & Theory & The material is in accordance with the & 4 \\
& & theme book used & 3 \\
2 & Module Contents & Structured module content & 4 \\
3 & Module view & Attractive module display & 2 \\
4 & Module language & Easy to understand & 2 \\
& & Provide clear information & $\mathbf{1 5}$ \\
\hline
\end{tabular}

In addition to the response questionnaire to the print module and electronic module, the instrument used is a tolerance character questionnaire after the implementation of the print module and electronic module. Table 1 shows a grid of student tolerance character questionnaire.

Table 2. Grid of Student Tolerance Character Questionnaire

\begin{tabular}{ccc}
\hline No & Assessment Aspect & Number of Items \\
\hline 1 & Be open to learning other people's beliefs and views. & 4 \\
2 & Can accept something new. & 4 \\
3 & Say politely & 3 \\
4 & Mutual respect and appreciation. & 4 \\
\hline & Total & $\mathbf{1 5}$ \\
\hline
\end{tabular}

For reliability is calculated using the Cronbach alpha formula. After the instrument was tested and analyzed for reliability, the reliability coefficient of the questionnaire implementation of the print module on the sharing indicator was 0.780 and for the electronic module on the indicators of cooperation with each other 0.720 so that it can be concluded that the instrument is reliable. The form of the questionnaire used is a closed questionnaire, namely for each question or statement a number of choice answers have been provided for respondents to choose from using the Likert category of a five rating scale. The dimensions of students' attitudes of tolerance studied were 2 indicators, namely those described in the table above. The students' tolerance attitude in this study used a Likert scale. Likert scale with the type of scale is very bad (STB), not good (TB), moderate (C), good (B), and very good (SB). Each positive item in the instrument has a score of: $\mathrm{STB}=5, \mathrm{~TB}=4, \mathrm{C}=3, \mathrm{~B}=2$, and $\mathrm{SB}=1$. Scores are reversed for negative items. This questionnaire data was given to the fifth grade students of SDN 45/I Sridadi.

Electronic module validation is the validation of several experts, namely linguists, material experts, media experts and expert practitioners. The four experts went through the stage of filling out the validation sheet which was sourced from the modified BSNP 2016 source. The instrument for assessing the validity of the electronic module based on local wisdom was compiled in the form of a Likert scale with positive statements. The data from the responses of several experts were analyzed in the following two steps, namely firstly adding up the total score of each expert for all indicators and secondly giving the validity value by using the method, the total score obtained was divided by the maximum score then multiplied by $100 \%$. The analysis of the validity of the module was carried out using descriptive statistics, the results of which were depicted through graphs. The validation score becomes a value with a range of 0-100. The data analysis used in this research is descriptive inferential statistics.

The data collection procedure used in this study is starts from identifying the problem to be studied and then finding the problem formulation to determine the research objectives. After that, the 
researcher determines the type of research, the population and the sample used to determine the sampling technique to be sampled. After determining the sample, the researcher determines the research instrument to determine how to collect the required data. Then the researcher validated the module, the data collection procedure and then the data carried out had to be determined by the data analysis technique, finally the results and discussion were obtained. The data analysis method used in this research is descriptive inferential statistical data analysis method. In this study, the data analysis methods used were the maximum value, minimum value, average/mean, normality test, homogeneity test and $t$ test.

\section{RESULT AND DISCUSSION}

Result

Based on the objectives of this study, namely to identify and find out how students respond when using the print module; how students respond when using electronic modules; how is the tolerance character when using the print module; and how the character of students' tolerance when using electronic modules in class V SDN 45/I Sridadi. Where the application of the electronic module based on local wisdom of ngubat padi has been validated by several material experts and media experts with the results obtained are $61-80 \%$ with a feasible category so that it can be applied as additional teaching material. To see student responses when using the print module, descriptive statistical analysis was used. The results of the student response questionnaire when using the print module in class V of SDN 45/I Sridadi can be seen in Table 3.

Table 3. Student Response Results When Using the Print Module

\begin{tabular}{|c|c|c|c|c|c|c|c|c|}
\hline \multicolumn{3}{|c|}{ Characteristics } & \multirow{2}{*}{ Mean } & \multirow{2}{*}{ Min } & \multirow{2}{*}{ Max } & \multirow{2}{*}{ Median } & \multirow{2}{*}{$\begin{array}{c}\text { Standar } \\
\text { Deviasi }\end{array}$} & \multirow{2}{*}{$\%$} \\
\hline Interval & Attitude & Total & & & & & & \\
\hline $\begin{array}{l}55-58 \\
59-62 \\
63-66 \\
67-70 \\
71-74\end{array}$ & $\begin{array}{l}\text { Not very good } \\
\text { Not good } \\
\text { Enough } \\
\text { Good } \\
\text { Very good }\end{array}$ & $\begin{array}{c}8 \\
11 \\
7 \\
3 \\
3\end{array}$ & 64,91 & 55 & 74 & 60 & 4.79404 & $\begin{array}{l}25 \\
31,42 \\
21,87 \\
9,37 \\
9,37\end{array}$ \\
\hline & Total & 32 & & & & & & 100 \\
\hline
\end{tabular}

The results from Table 3, can be seen that 9.37\% (3 of 32 students) are included in the very good and good categories, in the moderate category the results are $21.87 \%$ ( 7 of 32 students), in the poor category the results are $31,42 \%$ (11 of 32 students) and in the very bad category the results were $25 \%$ (8 people out of 32 students), therefore it can be seen that the student's response when using the print module is included in the weak category. Where this can be seen from the data on the number of students who have filled out a questionnaire containing several questions that have been processed by researchers and produce the data. To see student responses when using the electronic module, descriptive statistical analysis was used. The results of the student response questionnaire when using the electronic module in class V of SDN 45/I Sridadi can be seen in Table 4.

Table 4. Results of Student Responses When Using Electronic Modules

\begin{tabular}{|c|c|c|c|c|c|c|c|c|}
\hline \multicolumn{3}{|c|}{ Characteristics } & \multirow{2}{*}{ Mean } & \multirow{2}{*}{ Min } & \multirow{2}{*}{ Max } & \multirow{2}{*}{ Median } & \multirow{2}{*}{$\begin{array}{l}\text { Standar } \\
\text { Deviasi }\end{array}$} & \multirow{2}{*}{$\%$} \\
\hline Interval & Attitude & Total & & & & & & \\
\hline $\begin{array}{l}56-59 \\
60-63 \\
64-67 \\
68-71 \\
72-75\end{array}$ & $\begin{array}{l}\text { Not very good } \\
\text { Not good } \\
\text { Enough } \\
\text { Good } \\
\text { Very good }\end{array}$ & $\begin{array}{c}3 \\
2 \\
2 \\
15 \\
10\end{array}$ & 76,75 & 56 & 75 & 65 & 6.87885 & $\begin{array}{c}9,375 \\
6,25 \\
6,25 \\
46,875 \\
31,25\end{array}$ \\
\hline & Total & 32 & & & & & & 100 \\
\hline
\end{tabular}

While in the Table 4, using the electronic module, the results of the analysis carried out by researchers are $31.25 \%$ (10 of 32 students) which are included in the very good category and 46,875 are included in the good category, in the moderate category the results are $6.25 \%$. (2 people out of 32 students), in the bad category the results obtained $6.25 \%$ ( 2 out of 32 students) and in the very bad 
category the results obtained $9.375 \%$ ( 3 out of 32 students), therefore it can be seen that the students' responses to when the use of electronic modules can be said to be good. Where this can be seen from the data on the number of students who have filled out a questionnaire containing several questions that have been processed by researchers and produce the data. To see the character of students' tolerance when using the print module, descriptive statistical analysis was used. The results of the student tolerance character questionnaire when using the print module in class V of SDN 45/I Sridadi can be seen in Table 5.

Table 5. Results of Student Tolerance Characters When Using the Print Module

\begin{tabular}{|c|c|c|c|c|c|c|c|c|}
\hline \multicolumn{3}{|c|}{ Characteristics } & \multirow{2}{*}{ Mean } & \multirow{2}{*}{ Min } & \multirow{2}{*}{ Max } & \multirow{2}{*}{ Median } & \multirow{2}{*}{$\begin{array}{l}\text { Standar } \\
\text { Deviasi }\end{array}$} & \multirow[b]{2}{*}{$\%$} \\
\hline Interval & Attitude & Total & & & & & & \\
\hline $\begin{array}{l}58-61 \\
62-65 \\
66-69 \\
70-73 \\
74-77\end{array}$ & $\begin{array}{l}\text { Not very good } \\
\text { Not good } \\
\text { Enough } \\
\text { Good } \\
\text { Very good }\end{array}$ & $\begin{array}{c}4 \\
13 \\
3 \\
7 \\
5\end{array}$ & 67,08 & 58 & 77 & 63 & 4.77466 & $\begin{array}{c}12,5 \\
40,625 \\
9,375 \\
21,875 \\
15,625\end{array}$ \\
\hline & Total & 32 & & & & & & 100 \\
\hline
\end{tabular}

In Table 5, which is to see the tolerance character of students using the print module, the results of the analysis carried out by researchers are $15.625 \%$ ( 5 of 32 students) which are included in the very good category, 21,875 (7 of 32 students) are in the good category, on In the sufficient category the results obtained $9.375 \%$ (3 people from 32 students), in the bad category the results obtained $40.625 \%$ (13 out of 32 students) and in the very bad category the results obtained $12.5 \%$ (4 out of 32 students), therefore it can be seen that the tolerance character of students when using the print module can be said to be not good. Where this can be seen from the data on the number of students who have filled out a questionnaire containing several questions that have been processed by researchers and produce the data. To see the character of students' tolerance when using the electronic module, descriptive statistical analysis was used. The results of the student tolerance character questionnaire when using the electronic module in class V of SDN 45/I Sridadi can be seen in Table 6.

Table 6. Results of Student Tolerance Characters When Using Electronic Modules

\begin{tabular}{|c|c|c|c|c|c|c|c|c|}
\hline \multicolumn{3}{|c|}{ Characteristics } & \multirow[b]{2}{*}{ Mean } & \multirow[b]{2}{*}{ Min } & \multirow[b]{2}{*}{ Max } & \multirow[b]{2}{*}{ Median } & \multirow{2}{*}{$\begin{array}{l}\text { Standar } \\
\text { Deviasi }\end{array}$} & \multirow[b]{2}{*}{$\%$} \\
\hline Interval & Attitude & Total & & & & & & \\
\hline $60-63$ & Not very good & 1 & \multirow{5}{*}{73,01} & \multirow{5}{*}{60} & \multirow{5}{*}{79} & \multirow{5}{*}{70} & \multirow{5}{*}{6.91881} & 2125 \\
\hline $64-67$ & Not good & 4 & & & & & & $\begin{array}{c}3,125 \\
125\end{array}$ \\
\hline $68-71$ & Enough & 4 & & & & & & 12,5 \\
\hline $72-75$ & Good & 14 & & & & & & 12,5 \\
\hline \multirow[t]{2}{*}{$76-79$} & Very good & 9 & & & & & & 43,75 \\
\hline & Total & 32 & & & & & & 100 \\
\hline
\end{tabular}

In the Table 6, which is to see the character of students' tolerance using electronic modules, the results of the analysis carried out by researchers are $28.125 \%$ ( 9 of 32 students) which are included in the very good category, 43.75 (14 of 32 students) are in the good category, in the moderate category the results obtained $12.5 \%$ ( 4 people from 32 students), in the not good category the results were $12.5 \%$ ( 4 out of 32 students) and in the very bad category the results were $3.125 \%$ ( 1 out of 32 students), therefore it can be seen that the tolerance character of students when using electronic modules can be said to be good. Where this can be seen from the data on the number of students who have filled out a questionnaire containing several questions that have been processed by researchers and produce the data. To see if the data obtained are normal and homogeneous or not. So the researchers used the assumption test in the Table 7.

Table 7. Test for Normality and Homogeneity

\begin{tabular}{|c|c|c|c|}
\hline & Normality test & & Homogeneity Test \\
\hline Indicator & Print Module & Electronic Module & Electronic Module \\
\hline
\end{tabular}




\begin{tabular}{lllll}
\hline Statistik & $\mathbf{0 , 2 5 6}$ & $\mathbf{0 , 1 7 9}$ & $\mathbf{0 , 4 2 4}$ & $\mathbf{0 , 2 7 1}$ \\
Df & $\mathbf{2 2}$ & $\mathbf{2 2}$ & $\mathbf{4 4}$ & $\mathbf{4 2}$ \\
Sig & $\mathbf{0 , 0 0 1}$ & $\mathbf{0 , 0 6 4}$ & $\mathbf{0 , 6 0 5}$ & $\mathbf{0 , 5 1 9}$ \\
\hline
\end{tabular}

Table 7 shows the results of normality and homogeneity tests conducted in class V of SD Negeri 45/I Sridadi on the application of print modules and electronic modules to see student responses and student tolerance characters. Normality test can be said to be normal if the value of sig $>0.05$. To test the normality of the data used the Kolmogorov-Smirnov statistical test with a significance value of 0.05 with the hypothesis $\mathrm{H} 0=$ sample comes from a population that has a normal distribution, $\mathrm{H} 1=$ sample comes from a population that does not have a normal distribution. From the processed data, it can be seen that the application of the electronic module based on local wisdom has a sig value above 0.05 so it can be said to be normal. Independent t-test aims to determine whether there are significant differences between the two samples studied. Independent $t$-test is said to be significant if $\mathrm{p}<0.05$. Based on data analysis, it can be seen that after the t-test, it can be seen that there is a comparison of the application of the printed module and the electronic module to see the response and tolerance character of students. This shows that the application of the print module to see the response and tolerance character with the application of the electronic module to see the response and tolerance character has a significant comparison.

\section{Discussion}

The application of teaching materials in class V of SDN 45/I Sridadi got results, namely when the application of the print module it could be seen that the student's response was not good. This is because learning the print module is less varied and more boring. Meanwhile, when applying the electronic module, students are enthusiastic in participating in learning. It is evident in the table of comparison results between the application of electronic modules and print modules that the average value in the electronic module class is higher than the print module class with the average in the print module class being 64,91 while in the electronic module class it is 76,75 . The application of teaching materials in class $\mathrm{V}$ of SDN 45/I Sridadi got results, namely when the print module was applied, it could be seen that the tolerance character formed was less than when the electronic module was applied. This can be seen from the results of the questionnaire that has been analyzed. In the class that has been tested to see the tolerance character, it can be seen that the average produced in the electronic module class is 73,01 while in the print module class the average is 67,08 .

The data from the analysis of assumption testing and hypothesis testing shows that the resulting data is homogeneous and normal as seen from the data that shows a significant value. The homogeneity test in this study used Levene's Test from two independent samples. With the following test criteria: If Levene's test value or Sig> 0.05 then the variance is homogeneous, whereas if Levene's test value $<0.05$ then the variance is not homogeneous. From the table above, it can be seen that the homogeneity value is 0.424 on the print module and 0.271 on the electronic module, so that the data obtained can be said to be homogeneous, because the sig value $>0.05$. Normality test and homogeneity test are very important because at the initial assumption a linear regression equation is said to be good if the regression error/error is normally distributed and homogeneous (Sukestiyarno \& Agoestanto, 2017). While the hypothesis test seen from the t-test table is carried out to see whether the proposed hypothesis is acceptable or not. In the t-test analysis that has been carried out the proposed hypothesis can be well received, it can be seen in the table that the sig value is less than 0.05 .

Previous research said that printed modules could improve student learning outcomes, but electronic modules were better at improving student learning outcomes (Aji et al., 2020). There were results that student responses to electronic modules were well received and had higher practical values (Ratriana et al., 2021). The use of electronic modules is very effective in increasing students' learning motivation, besides that it is also effective for improving student learning outcomes, as well as critical thinking skills (Darmayasa et al., 2018; Hafsah et al., 2016; Puspitasari, 2019). Therefore, the application of the electronic module is considered to be better than the printed module because in addition to being practical, effective, and increasing student learning motivation, the electronic module can also improve learning outcomes much better than using the print module because it can increase students' critical thinking level. Indonesia as a pluralistic country has many differences in society, such as differences in religion, ethnicity, race, and class, so tolerance is needed to bridge these differences (Sari, 2017). However, tolerance has long faded in society. So that education must strive so that the character of tolerance is maintained to this day. The character of tolerance serves to grow students' multicultural competence. The phenomenon of intolerance cases needs to be prevented through the development of character education in schools (Supriyanto \& Wahyudi, 2017). Therefore, with this research, it is hoped 
that the character of tolerance can be maintained again by applying an electronic module based on local wisdom of ngubat padi with the wealth of values in it.

Based on the results obtained, this research has an enlightening meaning for an electronic module based on local wisdom of ngubat padi using the Kvisoft Flipbook Maker application, which meets the needs of the learning process, student characteristics, teaching materials and courses. electronic module development. This module combines the local wisdom of the Tebo Regency and adapts it to the 2013 curriculum applied in elementary schools. Electronic modules can be used as teaching aids, and their use is still in accordance with government books and student books. In this study, it was limited to being implemented in class V, theme 8, sub-theme 1 and learning 3 at SD 45/1 Sridadi. Therefore, the researcher hopes that readers, especially elementary school teachers, can use the electronic module that was developed as an alternative to 5th grade elementary school learning textbooks with a focus on theme 8, subtheme 1, learning 3 in other elementary schools.

\section{CONCLUSION}

The conclusion is that student responses are more dominant to the electronic module based on local wisdom of ngubat padi than to the printed module. The visible characters are also more dominant when using an electronic module based on local wisdom of ngubat padi than when using a printed module. Electronic modules strongly support classroom learning compared to print modules. Therefore, the researcher hopes that readers, especially elementary school teachers, can use the electronic module that was developed as an alternative to 5th grade elementary school learning textbooks with a focus on theme 8 , subtheme 1 , learning 3 in other elementary schools.

\section{REFERENCES}

Abdurokhim, A. (2016). Analisis Komparatif Penggunaan Sistem Informasi Perbankan antara Bank Syariah aan Bank Konvensional. Syntax Literate; Jurnal Ilmiah Indonesia, 1(1), 41-54. https://www.jurnal.syntaxliterate.co.id/index.php/syntax-literate/article/view/7.

Aji, N. K. B., Hadromi, H., \& Wijaya, M. B. R. (2020). Efektivitas Penerapan Modul Elektronik Sistem Injeksi Bahan Bakar Bensin untuk Meningkatkan Hasil Belajar Mahasiswa dalam Mata Kuliah Teori Motor Bakar. Journal of Mechanical Engineering Learning, 9(2), 1-1. https://journal.unnes.ac.id/sju/index.php/jmel/article/view/40434.

Al Aslamiyah, T., Setyosari, P., \& Praherdhiono, H. (2019). Blended Learning dan Kemandirian Belajar Mahasiswa Teknologi Pendidikan. Jurnal Kajian Teknologi Pendidikan, 2(2), 109-114. http://dx.doi.org/10.17977/um038v2i22019p109.

Anandari, Q. S., Kurniawati, E. F., Marlina, M., Piyana, S. O., Melinda, L. G., Meidiawati, R., \& Fajar, M. R. (2019). Pengembangan Modul Elektronik Motivasi Belajar Siswa Dengan Menggunakan Aplikasi Kvisoft Flipbook Berbasis Etnhokonstruktivisme. Pedagogik: Jurnal Pendidikan, 6(2), 416-436. https://doi.org/10.33650/pjp.v6i2.584.

Asrial, Syahrial, Maison, Kurniawan, D. A., \& Piyana, S. O. (2020). Ethnoconstructivism E-Module to Improve Perception, Interest, and Motivation of Students in Class V Elementary School. JPI Jurnal Pendidikan Indonesia), 9(1), 30-41. https://doi.org/10.23887/jpi-undiksha.v9i1.19222.

Bahiu, N., Mananeke, L., \& Loindong, S. (2015). Analisis Perbandingan Kinerja Produk Pada Produk Handphone Blackberry Dan Samsung (Studi Pada Mahasiswa Fakultas Ekonomi dan Bisnis Universitas Sam Ratulangi Manado). Jurnal EMBA: Jurnal Riset Ekonomi, Manajemen, Bisnis Dan Akuntansi, 3(1). https://doi.org/10.35794/emba.3.1.2015.8291.

Budiman, H. (2017). Peran teknologi informasi dan komunikasi dalam pendidikan. Al-Tadzkiyyah: Jurnal Pendidikan Islam, 8(1), 31-43. https://doi.org/10.24042/atjpi.v8i1.2095.

Bupu, S., Rukayah, R., \& Subiyantoro, S. (2018). Influence of Writing Poetry Module Using in Contextual Learning to Writing Poetry Learning Result of Elementary Student. International Journal of $\begin{array}{llll}\text { Multicultural and } \quad \text { Multireligious } & \text { Understanding, }\end{array}$ https://doi.org/10.18415/ijmmu.v5i2.229.

Chistolini, S. (2017). Education and the Paradigm of Tolerance. European Journal of Educational Sciences, 4(1), 42-52. https://www.ceeol.com/search/article-detail?id=853601.

Darmayasa, I. K., Jampel, I. N., \& Simamora, A. H. (2018). Pengembangan E-Modul Ipa Berorientasi Pendidikan Karakter Di SMP Negeri 1 Singaraja. Jurnal Edutech Undiksha, 6(1), 53-65. https://doi.org/10.23887/jeu.v6i1.20267.

Dewi, U., \& Susilowati. (2017). Development Electronic Module On Subject Matter Kalor For Junior High School Student. In 9th International Conference for Science Educators and Teachers (ICSET 2017), 
658-660. https://doi.org/10.2991/icset-17.2017.109.

Dewia, E. R., \& Alam, A. A. (2020). Transformation model for character education of students. Cypriot Journal of Educational Sciences, 15(5), 1228-1237. https://doi.org/10.18844/cjes.v15i5.5155.

Diputra, K. S. (2016). Pengembangan Multimedia Pembelajaran Tematik Integratif Untuk Siswa Kelas IV Sekolah Dasar. JPI (Jurnal Pendidikan Indonesia), 5(2), 125. https://doi.org/10.23887/jpiundiksha.v5i2.8475.

Etikan, I., Musa, S. A., \& Alkassim, R. S. (2015). Comparison of Convenience Sampling and Purposive Sampling. American Journal of Theoretical and Applied Statistics, 5(1), 1. https://doi.org/10.11648/j.ajtas.20160501.11.

Hafsah, N. R., Rohendi, D., \& Purnawan, P. (2016). Penerapan media pembelajaran modul elektronik untuk meningkatkan hasil belajar siswa pada mata pelajaran teknologi mekanik. Journal of Mechanical Engineering Education, 3(1), 106-112. https://doi.org/10.17509/jmee.v3i1.3200.

Hanani, D. (2016). Pendidikan karakter anak menurut Imam Al-Gazali. Jurnal Ilmiah AL-Jauhari: Jurnal Studi Islam Dan Interdisipliner, http://journal.iaingorontalo.ac.id/index.php/aj/article/view/663.

Herawati, N. S., \& Muhtadi, A. (2018). Pengembangan modul elektronik (e-modul) interaktif pada mata pelajaran Kimia kelas XI SMA. Jurnal Inovasi Teknologi Pendidikan, 5(2), 180-191. https://doi.org/10.21831/jitp.v5i2.15424.

Husaini, M. (2017). Pemanfaatan teknologi informasi dalam bidang pendidikan (e-education). Manajemen Informatika, 2(1). https://ojs.ummetro.ac.id/index.php/mikrotik/article/view/314.

Inah, E. N. (2013). Peranan komunikasi dalam pendidikan. Al-TA'DIB: Jurnal Kajian Ilmu Kependidikan, 6(1), 176-188. https://ejournal.iainkendari.ac.id/index.php/al-tadib/article/view/299/289.

Ismail, I., Anitah, S., Sunardi, S., \& Rochsantiningsih, D. (2019). Improving Fiqih Learning Quality through COPERSOL Model with Local Wisdom at Madrasah Tsanawiyah in Semarang. 1st International Conference on Innovation in Education (ICoIE 2018), 631-635. https://doi.org/10.2991/icoie18.2019.132.

Kaunang, C. A. (2013). Analisis perbandingan kinerja keuangan perusahaan menggunakan rasio profitabilitas dan economic value added pada perusahaan yang tergabung dalam LQ 45. Jurnal EMBA: Jurnal Riset Ekonomi, Manajemen, Bisnis Dan Akuntansi, 1(3). https://doi.org/10.35794/emba.1.3.2013.2140.

Kim, K., H., Arris, C. J., \& Pham, L. (2018). How character education impacts teachers. International Journal of Multidisciplinary Perspectives in Higher Education, 3(1). https://eric.ed.gov/?id=EJ1227264.

Kurniawan, A. R., Budiono, H., Hariandi, A., Marlina, M., Kurniawati, E. F., Meidiawati, R., \& Piyana, S. O. (2020). Investigasi Minat Belajar Terhadap Modul Elektronik Berbasis Etnokontruktivisme. Profesi Pendidikan Dasar, 2 93-104. https://journals.ums.ac.id/index.php/ppd/article/view/10650.

Kurniawati, E. F. (2020). Pengimplementasian e-modul etnokonstruktivisme terhadap motivasi belajar peserta didik Kelas V sekolah dasar. Jurnal Penelitian Ilmu Pendidikan, 13(1), 10-21. https://doi.org/10.21831/jpipfip.v13i1.26589.

Kusmana, S., Pujiatna, T., \& Gloriani, Y. (2020). The Development of Fabel Text Teaching Materials Based on Local Wisdom as Learning Scaffolding. The 3rd International Conference on Language, Literature, and Education (ICLLE 2020), 328-336. https://doi.org/10.2991/assehr.k.201109.054.

Kwon, H. (2017). Effects of 3D printing and design software on students' interests, motivation, mathematical and technical skills. Journal of STEM Education, 18(4). https://www.learntechlib.org/p/181996/.

Lestari, H. D., \& Parmiti, D. P. (2020). Pengembangan e-modul IPA bermuatan tes online untuk meningkatkan hasil belajar. Journal of Education Technology, 4(1), 73-79. https://doi.org/10.23887/jet.v4i1.24095.

Lukman, M., Istiyono, E., Kartowagiran, B., Retnawati, H., Adi, H. C., \& Kistoro, H. P. (2021). Effective teachers' personality in strengthening character education. International Journal of Evaluation and Research in Education (IJERE), 10(2), 512-521.

Maksum, A. (2012). Metodologi Penelitian dalam Olahraga. Unesa University Press.

Manurung, R., Sumantri, M. S., \& Utomo, E. (2018). Enhancing tolerance character through problem based learning model (PBL) based on simulation of social studies subject with the themes of diversity in my country. International Journal of Multidisciplinary and Current Research, 6, 835-839. http://ijmcr.com/wp-content/uploads/2018/07/Paper26835-839.pdf.

Mustadi, A., Murtiningsih, M., Lestari, D. P., \& Amalia, E. (2019). Sociocultural Based Descriptive Writing Skill Learning Module for Elementary School Students. KnE Social Sciences, 249-260. https://knepublishing.com/index.php/KnE-Social/article/view/4646. 
Nagovitsyn, R. S., Bartosh, D. K., Ratsimor, A. Y., \& Maksimov, Y. G. (2018). Formation of social tolerance among future teachers. European Journal of Contemporary Education, 7(4), 754-763. https: //eric.ed.gov/?id=EJ1200906.

Nurkhalisa, S., \& Ummayah, F. F. D. (2015). Etse-Module “The Benefits of Acidic Bases in Life" Ethnoscience Based Demak Society in the Utilisation of Lime. International Journal of Science and Research (IJSR), 6(7), 1396-1400.

Prasetiyowati, Y. (2015). Pengembangan modul elektronik pada mata pelajaran animasi 3 dimensi materi pokok pemodelan objek 3D Kelas XI multimedia untuk meningkatkan hasil belajar di SMK Negeri 1 Magetan. Jurnal Mahasiswa Teknologi Pendidikan, 6(2).

Proity, S. H. (2015). Effect of Joyful Teaching on Grade IV Students " Academic Performance in Science. International Journal of Science and Research (IJSR), 4(10), 1232-1240. https://pdfs.semanticscholar.org/0d1b/d23c899d03160e99db032044aa5cd985adde.pdf.

Purwanto, A., Nurjayadi, M., Suluya, R., \& Ichsan, I. Z. (2020). EM-SETS: An integrated e-module of environmental education and technology in natural science learning. International Journal of Advanced Science and Technology, 29(3), 7014-7025.

Puspitasari, A. D. (2019). Penerapan Media Pembelajaran Fisika Menggunakan Modul Cetak dan Modul Elektronik pada Siswa SMA. Jurnal Pendidikan Fisika, 7(1), 17-25. https: //core.ac.uk/download/pdf/234746944.pdf.

Rachmadyanti, P. (2017). Penguatan pendidikan karakter bagi siswa sekolah dasar melalui kearifan lokal. JPsd (Jurnal Pendidikan Sekolah Dasar), 3(2), 201-214. https://doi.org/10.30870/jpsd.v3i2.2140.

Rachmawati, Y., Pai, Y. F., \& Chen, H. H. (2014). The necessity of multicultural education in Indonesia. International Journal of Education and Research, 2(10), 317-328. https: //www.ijern.com/journal/2014/October-2014/25.pdf.

Ratriana, D., Purwoko, R. Y., \& Yuzianah, D. (2021). Pengembangan E-modul Berbasis Etnomatematika yang Mengeksplorasi Nilai dan Budaya Islam untuk Siswa SMP. AlphaMath: Journal of Mathematics Education, 7(1), 11-19. https://doi.org/10.30595/alphamath.v7i1.8498.

Ritzhaupt, A. D., Liu, F., Dawson, K., \& Barron, A. E. (2013). Differences in student information and communication technology literacy based on socio-economic status, ethnicity, and gender: Evidence of a digital divide in Florida schools. Journal of Research on Technology in Education, 45(4), 291-307. https://doi.org/10.30595/alphamath.v7i1.8498.

Saglam, H. I. (2011). An Investigation on Teaching Materials Used in Social Studies Lesson. Turkish Online Journal of Educational Technology-TOJET, 10(1), 36-44. https://eric.ed.gov/?id=EJ926552.

Sahal, M., Musadad, A. A., \& Akhyar, M. (2018). Tolerance in multicultural education: A theoretical concept. International Journal of Multicultural and Multireligious Understanding, 5(4), 115-122. https://doi.org/10.18415/ijmmu.v5i4.212.

Sanjaya, D. B., Suartama, I. K., Suastika, I. N., Sukadi, S., \& Dewantara, I. P. M. (2021). The implementation of balinese folflore-based civic education for strengthening character education. Cypriot Journal of Educational Sciences, 16(1), 303-316. https://doi.org/10.18844/cjes.v16i1.5529.

Sari, D. P. (2017). Penanaman Karakter Toleransi pada Siswa Reguler dan Siswa Berkebutuhan Khusus Melalui Pembelajaran PPKn di SMPN 4 Sidoarjo. Kajian Moral dan Kewarganegaraan. Kajian Moral Dan Kewarganegaraan, 5(2). https://jurnalmahasiswa.unesa.ac.id/index.php/index/index.

Subali, B., Sopyan, A., \& Ellianawati, E. (2015). Developing local wisdom based science learning design to establish positive character in elementary school. Jurnal Pendidikan Fisika Indonesia, 11(1), 1-7. https://journal.unnes.ac.id/nju/index.php/JPFI/article/view/3998.

Sugiyono. (2018). Metode Peneiltian Kuantitatif, Kualitatif dan R\&D. In Alfabeta Bandung.

Sukestiyarno, Y. L., \& Agoestanto, A. (2017). Batasan Prasyarat Uji Normalitas Dan Uji Homogenitas Pada Model Regresi Linear. Unnes Journal of Mathematics, 6(2), 168-177. https://journal.unnes.ac.id/sju/index.php/ujm/article/view/11887.

Supriyanto, A., \& Wahyudi, A. (2017). Skala karakter toleransi: konsep dan operasional aspek kedamaian, menghargai perbedaan dan kesadaran individu. Counsellia: Jurnal Bimbingan Dan Konseling, 7(2), 61-70. https://doi.org/10.25273/counsellia.v7i2.1710.

Suryani, S., Muryani, C., \& Yusup, Y. (2019). Development of Subject Specific Pedagogy Integrated with Local Wisdom to Improve Environmental Care Attitude of Elementary Students at Merapi Indonesia. Journal of Critical Reviews, 7(5). http://www.jcreview.com/fulltext/1971586591877.pdf. 